\title{
Recognizing Acceptance of Change and Organizational Support in Public Service Organizations: Engaging Middle Managers in Organizational Change
}

\author{
Safuwan Samah \\ Public Service Department of Malaysia, Malaysia
}

Received: March 27, 2018 Accepted: April 24, 2018 Online published: May 6, 2018

doi:10.5296/ijhrs.v8i2.12892ＵRL: https://doi.org/10.5296/ijhrs.v8i2.12892

\begin{abstract}
Despite the number of transformation plans were implemented by public service organizations, there is still lack of studies concerns on the employees' acceptance of change in the workplace. The purpose of this paper is to explore the direct influence of perceived organizational support and employee's acceptance of change by middle managers in Malaysian Public Service organizations. A total of 400 Administrative and Diplomatic Officers (ADO) were selected by using random sampling method and data for this study were collected using self-administered questionnaires. This study employed descriptive and Pearson Product-Moment Correlation to answer research objectives. The findings discovered that acceptance of change and organizational support is significantly positive correlated. Though this investigation may add knowledge to the body of literature on acceptance of change behavior and perceived organizational support, future researchers are encourage to explore the variables on different level of officers in public service organizations as well as to conduct differential study comprise of both public and private organizations.
\end{abstract}

Keywords: organizational change, perceived organizational support, acceptance of change, middle manager behavior, employee engagement, employee perception

\section{Introduction}

Today, changes are norms to public service organizations with the occurrence of industrial development, innovation, globalization, competition, and changes in regulations and consumer tastes (Pasmore, 2011). Constructive organizational change has become a necessity in determining the status of local government by implementing changes including transformation in strategic planning, modification of organizational structure and organizational patterns, adjustment of management models and revolution of employment laws (Nazariyan \& Rahimi, 2013). These changes will eventually give impact to the 
employees' work experience, attitudes and performances (Cullen, Edwards, Casper \& Gue, 2014). Subsequently, employee reactions, attitudes and beliefs towards changes will give impact to the process and outcome of that organizational changes implementation (Nielsen \& Randall, 2012). In the research field of organizational change, the change effort of an organization will only be more effective towards successful implementation when employees experience feeling of readiness for change and acceptance of change (Safuwan, 2018). Research revealed that the success of organizational change plans can be predicted through the level of acceptance of changes by employees of the organization (Augustsson, Richter, Hasson \& von Thiele Schwarz, 2017; Nielsen \& Randall, 2012; Oreg \& Sverdlik, 2011; Miller, Johnson \& Grau, 1994; Armenakis, Harris \& Mossholder, 1993).

Acceptance of change (AOC) behaviour among employees has become a critical part of today's organizational behaviour concerns and successful organizational climate (Augustsson, Richter, Hasson \& von Thiele Schwarz, 2017). Previously, employees usually resist to accepting the changes (Jabbarian \& Chegini, 2016) and their resistance to change used to be considered as a natural answer to organization (Jabbarian \& Chegini, 2016; Hadavinejad, Khaef Elahi \& Alizadeh Sani, 2009). When some staff resists to change, it is crucial for managers to identify the factors affecting employee resistance to change and they must be able to reduce it so that they can accept the changes for changes or transformation are able to be successfully implemented (Furst \& Cable, 2008). Generally, many researches concern on the employees specifically administrative and support staff, however, little is known on how employees in managerial level actually response and behave towards organizational changes.

As further researches have been conducted, perceived organizational support was proven to be directly and indirectly influence employees' readiness to change (Jabbarian \& Chegini, 2016). Employees used the organizational support they perceived to overcome challenges and threats during changes happened in the organization (Yu \& Lee, 2015). According to organizational support theory, employees will increase their commitment and give better performances as compensation to organization to the support they received (Taleghani, Divandri, Shir Mohammadi, 2009) by respecting to them and their work (Neves \& Eisenberger, 2014). Similarly, Social Exchange Theory also suggests that when people get a favor, they will feel that it is an obligation for them to compensate it (Jabbarian \& Chegini, 2016; Cropanzano \& Mitchell, 2005; Flynn, 2003; Wayne, Shore \& Liden, 1997).

Despite the large number of research in organizational field, there is surprisingly little research examining the direct influence of perceived organizational support and employee's acceptance of change (Cullen, Edwards, Casper \& Gue, 2014; Elias 2009; Walker, Armenakis \& Bernerth, 2007) especially in a specific workplace setting such as in public service organization, private sectors, government-link organization and non-profit organization as different setting may have different human resource practices that results to different responses from workers. Identifying the link between these two variables (i.e. perceived organizational support and acceptance of change) will add values to the knowledge as it can helps to improve understanding of employees' behaviour to the changes in their work environment. The research findings are expected to be able to provide practical recommendations for practitioners so that they can maximize employees' acceptance of 
change in order to implement the organization changes effectively.

\section{Literature Review}

Organizational support gives positive impacts to employees and organizations (Dirks \& Skarlicki, 2009). Eisenberger et al. (1986) described organizational support as an employee's perception of the organization's commitment to them. Specifically, past researches highlighted that organizational support is the level which an individual perceives his or her organization value and appreciates their contribution, compliments them and cares about their well-being (see Shoss, Eisenberger, Restubog, \& Zagenczyk, 2013; Dawley, Andrews, \& Bucklew, 2008; Eisenberger et al., 1986). Besides, some employees would consider perceived organizational support (POS) from other factors such as the willingness of organization and its members to assist and to provide equipments or facilities for them to fulfil their tasks; and to offer other opportunities (e.g. trainings) for their career development and advancement (Rhoades \& Eisenberger, 2002; LaMastro, 1999; Wayne et al., 1997; Shore \& Shore, 1995; Eisenberger et al., 1986).

Research has discovered that organizational support has significant influence towards employee's workplace intentions and behaviours (Ozyilmaz, 2010). Employees developed such positive impression towards the support they received from organization that lead to positive behaviour that benefited both employees and organization (Cullen, Edwards, Casper $\&$ Gue, 2014). Other research highlighted that building support is one of the effort from organization to overcome the resistance of change (Khan \& Hashim, 2014). In other words, support must be offered by organizations to the employees as an effort to shape the positive acceptance of change behaviour.

A study employed by Parker and Griffin (2011) disclosed that organizational resources such as perceived organizational support gives impact to employee engagement. In support to this finding, Aktar and Pangil (2017) was later ratified that workers no longer showing a low level of engagement when they perceived high level of support from their organization which the same research specified the concept of employee engagement includes employees' positive dedication to fulfil their tasks with regard to any organizational strategic plans to be implemented.

Although organizational support has been commonly used to measure an organization's treatment towards their employees in terms of how the organization values and supports the employees' work roles, present research still argued that their perception on organizational support could solely based on the equality of rewards to be distributed to compensate their effort in achieving the organizational objectives (Safuwan, 2017). Despite the argument, the same research highlighted that the fundamental of organizational support is still seen a way that employees develop with respect to the employee's exchange relationship with the organization.

Past research on attitudes and behaviours of employees revealed that organizational support is one of the best predictors which in turn give benefits to the organizations through their feelings of trust, long-term obligations, organizational identification among employees, 
higher performance, enhanced citizenship behaviours, and affective commitment to the organization (Rhoades \& Eisenberger, 2002) which then make them more obligated to achieve the organization objectives (Eisenberger, Armeli, Rexwinkel, Lynch, \& Rhoades, 2001).

Research on the attitudes and behaviours of employees was later extended to the context of organizational change and how employees respond during the process of implementation. Research advocated that organizational support is linked to evaluations of respect, which in turn could influence the volatility of individuals' engagement and contribution to the organization, one aspect of which is acceptance of change (Ngo et al., 2012).

The literature on individual behaviour in workplace setting has increasingly conducted found that perceived organizational support has positively influence the recipients' behaviour. Yet, little is known about the about the employees' acceptance of change on their perception of organizational support they received. Present research examines these antecedents to explain the contribution of perceived organizational support on acceptance of change among Management and Professional Group of Administrative and Diplomatic Officers in Malaysia Public Service organizations. In this study, organizational support refers to the respondents' perception that the higher management group values their contributions, compliments them, and genuinely cares about their well-being.

\subsection{Theoretical Assumption: Organizational Support Theory (OST)}

Organizational Support Theory (OST) was developed from the social exchange perspective in order to explain the member-organization relationship (Ngo et al., 2012). This theory was introduced by Eisenberger, Huntington, Hutchison, and Sowa (1986) to predict employees' belief and perception in regard to the extent to which organization concerns about their needs and well-being. This theory also highlighted that the perceived organizational support is a positive affirmation by organization to support employees when they successfully performed in doing their job (Kurtessis, Eisenberger, Ford, Buffardi, Stewart, \& Adis, 2017; Worley, 2006). Consequently, the perceived organizational support will significantly influence to employees' positive behaviour.

Eisenberger et al. (1986) described perceived organizational support as "a global beliefs about the extent to which the organization cares about their wellbeing and values their contributions. Accordingly, the same research constructed 36 items to measure the employee's beliefs on the support given by organization. Past researches have specified perceived organization support as supervisory support, diverse types of rewards and working environment (Rhoades \& Eisenberger, 2002), career development opportunities to broaden their knowledge and skills (Wayne, Shore \& Liden, 1997), minimum supervision to carry out the tasks given and autonomy to make decision (Eisenberger, Rhoades \& Cameron, 1999) and recognition and appreciation from top management and organization (Wayne, Shore, Bommer \& Tetrick, 2002). Hence, the nature of perceived organizational support can be varied depending on the work setting with the influence of political, economic and social environment (Naotunna \& Arachchige, 2016). 
This theory also emphasized that employees will develop positive or negative impression towards organization they serve, and it is depending on organization's capability to provide them support with adequate resources and appreciates them as individuals with rewards and compensations; and help them in difficult situation during the implementation of change (Cullen, Edwards, Casper \& Gue, 2014; Rhoades \& Eisenberger 2002; Shore \& Shore 1995; Eisenberger et al., 1986). Research later conceded that impressions will be positive if they receive sufficient organizational support as they expect. Subsequently, the formation of a positive impression resulting from it, will lead to positive outcomes to both parties individuals and organizations (Cullen, Edwards, Casper \& Gue, 2014). In regard to this theory, a study by Blau (1964) proved that after gaining supports need from organization, employees will feel indebted and hence, they will pun an effort to give back to the organization with their full commitment to perform their duties well. In contrast, if employees believe that the organization does not support them, they may detain themselves which results to low performance and negative attitudes and behaviours (Cullen, Edwards, Casper \& Gue, 2014).

Research by Rhoades et al. (2001) and Eisenberger et al. (2001) also highlighted that the perceived organization concerns about its employees will galvanizes employees' feeling of obligation to serve better for their organization, that later will creates a stronger attachment to the organization (Eisenberger, et al., 2001; Rhoades, et al., 2001; Wayne, et al., 1997; Eisenberger, et al., 1986; Mowday, et al., 1982). Rhoades and Eisenberger (2002) found that perceived organizational support has significant impact on employees' job satisfaction and job performance. Thus, this study replicates these finding and propose to the current study that employees who perceived organizational support will behave positively in accepting the organizational changes.

\section{Method}

\subsection{Sample and Procedure}

The sample consisted of 400 middle managers in public sector organizations in Malaysia. Specifically, the respondents were among 6,904 Management and Professional Group of ADO who served with Malaysia's government under 25 ministries. Researcher only selected ADOs between Grade 41 to Grade 54, since researcher anticipated that they are the middle managers that act as agent of change in the implementation of government strategic plans towards transformation. Researcher has obtained permission from the respective organizations to conduct the survey using self-administered questionnaires that were distributed and collected afterwards.

\subsection{Measurement}

Researched measured acceptance of change using 9 items from Organizational Change Questionnaire (OCQ) by Bouckenooghe, Devos, and Broeck (2009). Organizational support was measured using 8 items from Perceived Organizational Support questionnaires by Eisenberger, Huntington, Hutchison, and Sowa (1986). For acceptance of change, a sample item is "I have given my full commitment to the process of Public Service Transformation", 
and for organizational support, "My organisation really cares about my well-being”. With respect to the statements for research instruments, the respondents' levels of agreements were indicated using five-point Likert scale ranging from 1 "strongly disagree" to 5 "strongly agree".

\subsection{Analysis of Data}

Before the questionnaires were distributed to the actual respondents, a total of 30 respondents were selected from the population for the purpose of pilot analysis. After the questionnaires were collected, the researcher conducted the reliability tests on the research instruments used in this study by computing the Cronbach alpha coefficient. Based on Pallant (2010), the purpose of this test is to measure the consistency of the measured instruments used. The acceptable Cronbach alpha as suggested by Nunnally (1978) is .70. Table 1 shows reliability for research variables i.e. acceptance of change and organizational support.

Table 1. Coefficient Alpha of Pilot Testing and Actual Sample

\begin{tabular}{lcll}
\hline Research Variables & No. of items & $\begin{array}{l}\text { Cronbach Alpha } \\
(\mathrm{n}=30)\end{array}$ & $\begin{array}{l}\text { Cronbach Alpha } \\
(\mathrm{n}=400)\end{array}$ \\
\hline Acceptance of change & 8 & .840 & .836 \\
Organizational support & 9 & .772 & .880 \\
\hline
\end{tabular}

\section{Results}

Table 2. Demographic Profiles of the Respondents ( $n=400)$

\begin{tabular}{lll}
\hline Profile & Frequency & Percentage \\
\hline Gender & 158 & \\
Male & 242 & 39.5 \\
Female & & 60.5 \\
Age (years) & 59 & \\
$20-30$ & 257 & 14.8 \\
$31-40$ & 73 & 64.3 \\
$41-50$ & 11 & 18.3 \\
51 and above & & 2.8 \\
Marital Status & 105 & 26.3 \\
Single & 295 & 73.8 \\
Married & & \\
Education Level & 257 & 64.3 \\
Degree & 139 & 34.8 \\
Master & 4 & 1.0 \\
PhD & & \\
Grade Level & 203 & 50.8 \\
$41-44$ & 104 & 26.0 \\
48 & 55 & 13.8 \\
52 & 38 & 9.5 \\
54 & & 20.3 \\
Tenure (years) & 81 & 42.3 \\
$1-5$ & 169 & 27.0 \\
$6-10$ & 108 & 10.5 \\
$11-15$ & 42 & \\
16 and above & & \\
\hline
\end{tabular}

Descriptive analysis was conducted, and the respondents' demographic characteristics are as 
shown in Table 2. From a total of 400 respondents participated in this study, $39.5 \%$ were males and 60.5 were females. More than half (64.3\%) of respondents were between 31 and 40 years old. They were also predominantly by those who are married $(73.8 \%)$ and those who has bachelor's degree as their highest education level (64.3\%). This analysis also shows that slightly more than half of them $(50.8 \%)$ and nearly half $(42.3 \%)$ had served with the government for six (6) to ten (10) years.

Acceptance of change that involves the employees' commitment and participation to organizational change had the overall mean value of 2.19 and standard deviation of .41 as shown in Table 3. This study also showed that more than half of the respondents have high level of acceptance of change (57.0\%). A total of $41.8 \%$ of respondents are at the moderate level and only $1.3 \%$ at low level.

Table 3. Distribution of respondents based on level for acceptance of change $(n=400)$

\begin{tabular}{lrrrr}
\hline Research variables & Frequency & Percentage (\%) & Mean & SD \\
\hline Acceptance of Change & 5 & & 2.19 & .41 \\
Low $(1.00-2.33)$ & 167 & 41.8 & & \\
Moderate $(2.34-3.66)$ & 228 & 57.0 & & \\
High $(3.67-5.00)$ & & & \\
\hline
\end{tabular}

Organizational support which represents the employees' perception whether the organization concerns about their well-being had higher mean (2.29) compare to acceptance of change and standard deviation of .57. However, data in Table 4 shows that a bigger proportion of respondents $(59.3 \%)$ perceived moderate level of organizational support. From 400 respondents, $34.8 \%$ regarded the support they received from organization is high and $6.0 \%$ is low.

Table 4. Distribution of respondents based on level for organizational support $(n=400)$

\begin{tabular}{lrrrr}
\hline Research variables & Frequency & Percentage $(\%)$ & Mean & SD \\
\hline Organizational support & & & 2.29 & .57 \\
Low $(1.00-2.33)$ & 24 & 6.0 & & \\
Moderate $(2.34-3.66)$ & 237 & 59.3 & & \\
High $(3.67-5.00)$ & 139 & 34.8 & & \\
\hline
\end{tabular}

The mean and standard deviation of items measuring both variables i.e. acceptance of change and organizational support are presented in Table 5. The means for all items were above three on five-point scale of measurement. This study presents the highest mean among 9 items to measure acceptance of change was "I have given my full commitment to the process of Public Service Transformation" and the lowest mean was "Most Public Service Transformation initiatives that I have implemented will not do much good".

For the organizational support, researcher indicated that the middle managers of ADO involved in this study perceived a highly reasonable support from their organizations. Result revealed the item with the highest mean was "My organization cares about my opinions", while item with the lowest mean was "If given the opportunity, my organization would take advantage on me". 
Table 5. Means and standard deviations of items measuring

\begin{tabular}{lrc}
\hline Items & Mean & SD \\
\hline Acceptance of change & & \\
\hline I have encouraged others to see Public Service Transformation as refreshing. & 3.87 & 0.75 \\
I have shown my responsibility to Public Service Transformation willingly. & 3.64 & 0.79 \\
I have participated in the Public Service Transformation as a positive process. & 3.82 & 0.68 \\
I have made the changes in the Public Service Transformation which gave a & 3.77 & 0.90 \\
negative effect on the stakeholder. & & \\
I have given my full commitment to the process of Public Service & 3.91 & 0.63 \\
Transformation. & 3.39 & 1.00 \\
The plans that I have made for future improvement will not come too much. & 3.68 & 0.74 \\
I have made a significant contribution to the Public Service Transformation. & 3.31 & 1.06 \\
Most Public Service Transformation initiatives that I have implemented will & & \\
not do much good. & 3.80 & 0.68 \\
\hline I have put my energy into the public service transformation. & 3.51 & 0.88 \\
\hline Organizational support & 3.03 & 0.98 \\
My organization really cares about my well-being. & 3.38 & 0.84 \\
If given the opportunity, my organization would take advantage on me. & 3.62 & 0.77 \\
My organization strongly considers my goals and values. & 3.53 & 0.82 \\
My organization cares about my opinions. & 3.12 & 0.94 \\
My organization is willing to help me if I need a special favour. & 3.61 & 0.80 \\
My organization shows very little concern for me. & 3.53 & 0.85 \\
\hline Help is available from my organization when I have a problem. & \\
My organization would forgive an honest mistake on my part. &
\end{tabular}

Table 6 shows the result of correlation between two variables of this study. The finding reveals that there is a positive significant relationship between acceptance of change and organizational support $(\mathrm{r}=.464, \mathrm{p}<.001)$. Based on the Rule of Thumbs by Guildford, 1973, the $r$ value between these two variables is considered low correlated.

Table 6. Pearson Product-Moment Correlation between measures of acceptance of change and organizational support $(\mathrm{n}=400)$

\begin{tabular}{llrr}
\hline Items & & Mean & SD \\
\hline Acceptance of change & Pearson Correlation & 1 & $.464 * *$ \\
& Sig. (2-tailed) & & .000 \\
& $\mathrm{~N}$ & 400 & 400 \\
\hline Organizational support & Pearson Correlation & $.464 * *$ & 1 \\
& Sig. (2-tailed) & .000 & \\
& $\mathrm{~N}$ & 400 & 400 \\
\hline
\end{tabular}

\section{Discussion}

In terms of acceptance of change, researcher proved that the employees involved in this study has positive behavioral response towards organizational changes since their role as middle managers require them to be able to quickly adapt with all kinds of changes within their work setting. Being the middle managers, particularly as Administrative and Diplomatic Officers in Malaysia Public Service organizations, they have gone through trainings and are more likely to have experience to be involved directly in public services transformational plans. This is essential so when the managers behave positively towards organizational changes, they may 
influence other workers especially administrative and support staff to provide better services to serve public interest and needs. Subsequently, acceptance of change behaviour is essential as it leads to the employee's commitment in ensuring the successful of organization transformational plans (Augustsson, Richter, Hasson \& von Thiele Schwarz, 2017; Nielsen \& Randall, 2012; Oreg \& Sverdlik, 2011; Bouckenooghe, Devos, \& Broeck, 2009). Contrary to research by Jabbarian and Chegini (2016) and Hadavinejad et al. (2009), this research argue that resistance of change is not a natural answer to public service organization in Malaysia especially among middle managers as study discovered high level of acceptance of change among respondents of this study.

For organizational support, researcher was keen to know the middle managers perception whether they perceived adequate support from their organization. As described by Eisenberger et al. (1986), precisely, researcher intended to explore their perception on the organizational commitment to them. The results show that in public service organizations, middle managers have perceived moderate level of organizational support. Generally, public service organizations in Malaysia have gone through and still going through many transformational plans since the past 5 years. In this kind of situation, employees seek for organizational support such as organizations' appreciation towards their contributions, compliments them by giving recognition or promotion and care about their well-being by providing them access or aid in creating good working condition (Kubuga, 2014; Shoss, Eisenberger, Restubog, \& Zagenczyk, 2013; Dawley, Andrews, \& Bucklew, 2008; Eisenberger et al., 1986). Hence, it can be predicted that middle managers will have higher expectation on organizational support they may need to perceive.

As further analysis was conducted, present research discovered that organizational support has positive significant impact towards acceptance of change among Management and Professional Group of Administrative and Diplomatic Officers in Malaysia Public Service organizations. In line with research done by Ngo et al. (2012), the result of this study able to prove that support offered by organizations can influence significantly towards employees' positive behaviour during transformational process. Contrary to expectation, in this research however, middle managers among Administrative and Diplomatic Officers in Malaysia Public Service organizations showed low influence of perception of perceived organizational support on their acceptance of organizational change. According to an article written by Malek Shah (2003), Management and Professional Group of Administrative and Diplomatic Officers are required to attend various trainings during the entry level as well as before promotion from one level to another higher level. During the entry level, they have obtained a six months training of Diploma in Public Management course which also consist of many courses including Leading Change. Despite the moderate level of perceived organizational support, present study presumes that the distinct result of perceived organizational support influence on their acceptance of organizational change may caused by their knowledge, skills and competency have already prepared to adapt to transformation that may occur during their service. 


\section{Conclusion and Recommendations}

Overall, the Administrative and Diplomatic Officers experienced reasonably high level of acceptance of change, moderate level of perceived organizational support and low correlation between these two variables. This exploratory study, practically serves as an effort to understand the behavior towards changing environment and the perception of organizational support perceived among middle managers of public service organizations in Malaysia. The results may add knowledge to the body of literature on acceptance of change behavior and perceived organizational support in public service organizations and to some extent may fulfill the need of such study. Practically, the results can be applying to future research on management officers in managerial levels of public service organizations, especially those that have been through similar trainings as respondent of this study. This study has contributed to the field of human resource development (HRD) and organizational development (OD) generally. HRD is the integrated use of training and development, organizational development and career development in order to improve individual, group and organization's performance (McLagan, 1989; Ismail \& Osman-Gani, 2011). Since organizational development is one of the core threads of HRD, therefore, the contribution to acceptance of change behaviour as the field of study would also provide an added value to HRD as the body of knowledge that governed the study.

This study involved Malaysian Administrative and Diplomatic Officers scheme - being one of the schemes in Malaysia public service organizations that have gone through comprehensive trainings and courses to confirm their position at the beginning of their career as well as their succession planning. Therefore, the results may not be generalized to other schemes especially those in non-managerial group such as supporting staff. To be able to establish the generalizability of findings, it would be desirable for future researchers to explore the variables on different level of officers in public service organizations. Future researches are also encourage to conduct differential study comprise of both public and private organizations. In understanding the reality of workplace deviance, qualitative approach in particular ethnographic might be a methodology that could be adapted in subsequent research. It would be interesting if future studies on acceptance of change could be conducted in a qualitative manner, as this kind of research may generate knowledge based on individual experiences relating to the acceptance of organizational change.

\section{References}

Aktar, A., \& Pangil, F. (2017). The relationship between employee engagement, HRM practices and perceived organizational support: Evidence from banking employees. International Journal of Human Resource Studies, 7(3), 1-22. https://doi.org/10.5296/ijhrs.v7i3.11353

Armenakis, A. A., Harris, S. G., \& Mossholder, K. W. (1993). Creating readiness for organisational change. Human relations, 46(6), 681-703. https://doi.org/10.1177/001872679304600601

Augustsson, H., Richter, A., Hasson, H., \& von Thiele, S. U. (2017). The need for dual 
openness to change: a longitudinal study evaluating the impact of employees' openness to organisational change content and process on intervention outcomes. The Journal of Applied Behavioural Science. https://doi.org/10.1177/0021886317691930

Blau, P. (1964). Power and exchange in social life. NY: John Wiley \& Sons.

Bouckenooghe, D., Devos, G., \& Broeck, V. D. H. (2009). Organizational change questionnaire-climate of change, processes, and readiness: Development of a new instrument. The Journal of psychology, 143(6), 559-599. https://doi.org/10.1080/00223980903218216

Cropanzano, R., \& Mitchell, M. S. (2005). Social exchange theory: An interdisciplinary review. Journal of management, 31(6), 874-900. https://doi.org/10.1177/0149206305279602

Cullen, K. L., Edwards, B. D., Casper, W. C., \& Gue, K. R. (2014). Employees' adaptability and perceptions of change-related uncertainty: Implications for perceived organisational support, job satisfaction, and performance. Journal of Business and Psychology, 29(2), 269-280. https://doi.org/10.1007/s10869-013-9312-y

Dawley, D. D., Andrews, M. C., \& Bucklew, N. C. (2008). Mentoring, supervisor support, and perceived organisational support: what matters most?. Leadership Organisational Development, 29(3), 235-247. https://doi.org/10.1108/01437730810861290

Dirks, K. T., \& Skarlicki, D. P. (2009). The relationship between being perceived as trustworthy by coworkers and individual performance. Journal of Management, 35(1), 136-157. https://doi.org/10.1177/0149206308321545

Eisenberger, R., Armeli, S., Rexwinkel, B., Lynch, P. D., \& Rhoades, L. (2001). Reciprocation of perceived organizational support. Journal of applied psychology, 86(1), 42. https://doi.org/10.1037/0021-9010.86.1.42

Eisenberger, R., Huntington, R., Hutchinson, S., \& Sowa, D. (1986). Perceived organisational support. Journal of Applied Psychology, 71(3), 500-507. https://doi.org/10.1037/0021-9010.75.1.51

Eisenberger, R., Rhoades, L., \& Cameron, J. (1999). Does pay for performance increase or decrease perceived self-determination and intrinsic motivation?. Journal of Personality and Social Psychology, 77(5), 1026. https://doi.org/10.1037/0022-3514.77.5.1026

Elias, S. M. (2009). Employee commitment in times of change: Assessing the importance of attitudes toward organisational change. Journal of Management, 35(1), 37-55. https://doi.org/10.1177/0149206307308910

Flynn, F. J. (2003). How much should I give and how often? The effects of generosity and frequency of favor exchange on social status and productivity. Academy of Management Journal, 46(5), 539-553. https://doi.org/10.2307/30040648

Furst, S., \& Cable, D. (2008). Employee resistance to organizational change: Managerial influence tactics and leader-member exchange. Journal of Applied Psychology, 93(2), 453-462. https://doi.org/10.1037/0021-9010.93.2.453 
Hadavinejad, M., Khaef, E. A., \& Alizadeh, S. M. (2009). Politicians, managers, employees and political understanding of resistance to change. Iran Management Science, 4(16), 119-137.

Ismail, M., \& Osman, G. A. M. (2011). Human resource development in Malaysia.

Jabbarian, J., \& Chegini, M. G. (2017). The Effect of Perceived Organizational Support on Employee Resistance to Change: A Study on Guilan Municipal Staff. Journal of History Culture and Art Research, 5(4), 642-654. https://doi.org/10.7596/taksad.v5i4.627

Khan, M. A., \& Hashim, M. (2014). Organizational Change: Case Study of General Motors. ASEE 2014 Zone I Conference, April 3-5, 2014, University of Bridgeport, Bridgpeort, CT, USA.

Kubuga, K. (2014). Assessing the impact of organizational support on training and development: A case study of the University for Development Studies (Doctoral dissertation).

Kurtessis, J. N., Eisenberger, R., Ford, M. T., Buffardi, L. C., Stewart, K. A., \& Adis, C. S. (2017). Perceived organizational support: A meta-analytic evaluation of organizational support theory. Journal of Management, 43(6), 1854-1884. https://doi.org/10.1177/0149206315575554

LaMastro, V. (1999). Commitment and perceived organizational support. National Forum of Applied Educational Research Journal, 12(3).

Malek, S. B. M. Y. (2003). Globalization and human resource development in the Malaysian public service. Retrieved from http://unpan1.un.org/intradoc/groups/public/documents/eropa/unpan014373.pdf.

McLagan, P. A. (1989). Models for HRD practice. Training \& development journal, 43(9), 49-60.

Miller, V. D., Johnson, J. R., \& Grau, J. (1994). Antecedents to willingness to participate in a planned organisational change.

Mowday, R. T., Porter, L. W., \& Steers, R. (1982). Organizational linkage: the psychology of commitment, absenteeism and turnover. Organizational and Occupational Psychology, 10(3), 2008 .

Mowday, R. T., Porter, L. W., \& Steers, R. M. (1982). Employee-organization linkage. The psychology of commitment absenteism, and turn over. Academic Press Inc. London.

Naotunna, S., \& Arachchige, B. (2016). Perceived Organizational Support and Non-Managerial Employees' Commitment to Change in Sri Lankan Apparel Firms. South Asian Journal of Human Resources Management, 3(1), 40-57. https://doi.org/10.1177/2322093716637167

Nazarian, A., \& Rahimi, M. (2013). The need to review and select the best model management model in Tehran. Urban Management, 31, 138-125. 
Neves, P., \& Eisenberger, R. (2014). Perceived organisational support and risk taking. Journal of Managerial Psychology, 29(2), 187-205. https://doi.org/10.1108/JMP-07-2011-0021

Ngo, H., Loi, R., Foley, S., Zheng, X., \& Zhang, L. (2012). Perceptions of organisational context and job attitudes: The mediating effect of organisational identification. Asia Pacific Journal of Management, 1-46. https://doi.org/10.1007/s10490-012-9289-5

Nielsen, K., \& Randall, R. (2012). The importance of employee participation and perceptions of changes in procedures in a teamworking intervention. Work \& Stress, 26(2), 91-111. https://doi.org/10.1080/02678373.2012.682721

Nunnally, J. C. (1978). Psychometric Theory (2nd ed.). New York, NY: McGraw-Hill.

Oreg, S., \& Sverdlik, N. (2011). Ambivalence toward imposed change: the conflict between dispositional resistance to change and the orientation toward the change agent. Journal of Applied Psychology, 96(2), 337. https://doi.org/10.1037/a0021100

Ozyilmaz, A. (2010). Vertical trust in organisations: A review of empirical studies over the last decade. Journal of Social Sciences Institute, 7(13), 1-28.

Pallant, J. (2010). SPSS Survival Manual: A Step by Step Guide to Data Analysis using SPSS (4th Eds). Open University Press/McGrawHill, Maidenhead.

Parker, S. K., \& Griffin, M. A. (2011). Understanding active psychological states: Embedding engagement in a wider nomological net and closer attention to performance. European Journal of Work and Organizational Psychology, 20(1), 60-67. https://doi.org/10.1080/1359432X.2010.532869

Pasmore, W. A. (2011). Tipping the balance: Overcoming persistent problems in organizational change. In Research in organizational change and development (pp. 259-292). Emerald Group Publishing Limited. https://doi.org/10.1108/S0897-3016(2011)0000019011

Rhoades, L., \& Eisenberger, R. (2002). Perceived organisational support: A review of the $\begin{array}{llll}\text { literature. Journal of Applied Psychology, 87(4), 698-714. } & \text {. }\end{array}$ https://doi.org/10.1037/0021-9010.87.4.698

Rhoades, L., Eisenberger, R., \& Armeli, S. (2001). Affective commitment to the organization: The contribution of perceived organizational support. Journal of Applied Psychology, 86(5), 825. https://doi.org/10.1037/0021-9010.86.5.825

Safuwan, S. (2017). Mediating effect of organisational support on the relationships between individual, environmental factors and acceptance of change among Malaysian government officers (Doctoral dissertation). Universiti Putra Malaysia.

Safuwan, S. (2018). Acceptance of change behaviour among middle managers: The importance of subjective norms and social influence as environmental predictors. Asian Social Science, 14(2), 155. https://doi.org/10.5539/ass.v14n2p155

Shore, L. M., \& Shore, T. H. (1995). Perceived organizational support and organizational 


\section{Macrothink}

International Journal of Human Resource Studies

ISSN 2162-3058 2018, Vol. 8, No. 2

justice. Organizational Politics, Justice, and Support: Managing the Social Climate of the Workplace, 149-164.

Shoss, M. K., Eisenberger, R., Restubog, S. L. D., \& Zagenczyk, T. J. (2013). Blaming the organisation for abusive supervision: The roles of perceived organisational support and supervisor's organisational embodiment. Journal of Applied Psychology, 98(1), 158-168. https://doi.org/10.1037/a0030687

Taleghani, G. H., Divandri, A., Shir, M. M. (2009). The impact of perceived organizational support on employee engagement and organizational performance: A study in branches of bank mellat in Tehran, Iran. Management Science, 4(16), 1-25.

Walker, J. H., Armenakis, A. A., \& Bernerth, J. B. (2007). Factors influencing organizational change efforts: An integrative investigation of change content, context, process and individual differences. Journal of Organizational Change Management, 20(6), 761-773. https://doi.org/10.1108/09534810710831000

Wayne, S. J., Shore, L. M., \& Liden, R. C. (1997). Perceived organizational support and leader-member exchange: A social exchange perspective. Academy of Management journal, 40(1), 82-111. https://doi.org/10.2307/257021

Wayne, S. J., Shore, L. M., Bommer, W. H., \& Tetrick, L. E. (2002). The role of fair treatment and rewards in perceptions of organizational support and leader-member exchange. Journal of Applied Psychology, 87(3), 590. https://doi.org/10.1037/0021-9010.87.3.590

Worley, J. A. (2006). Factor Analytic Study to Evaluate the Structure of the Survey of Perceived Organizational Support (Doctoral dissertation). Oklahoma State University.

Yu, M, \& Lee, M. (2015). Unlocking the black box: exploring the link between perceive organizational support and resistance to change. Asia Pacific Management, 20, 121213121

\section{Copyright Disclaimer}

Copyright for this article is retained by the author(s), with first publication rights granted to the journal.

This is an open-access article distributed under the terms and conditions of the Creative Commons Attribution license (http://creativecommons.org/licenses/by/4.0/). 